\section{Formation of Pore Structure in Zirconia-Alumina Ceramics}

ALES S. BUYAKOV - Institute of Strength Physics and Materials Science of Siberian Branch of Russian Academy of Sciences - National Research Tomsk State University - alesbuyakov@gmail.com

RusLAN V. LEVKOV - Institute of Strength Physics and Materials Science of Siberian Branch of Russian Academy of Sciences = National Research Tomsk Polytechnic University - levkov.r.v@mail.ru

SvetLana P. BUYAKOVA - Institute of Strength Physics and Materials Science of Siberian Branch of Russian Academy of Sciences - National Research Tomsk State University • sbuyakova@ispms.ru

EMESE KUROVICS - Institute of Ceramics and Polymer Engineering - University of Miskolc • fememese@uni-miskolc.hu

LÁszLó A. GÖMZE - Institute of Ceramics and Polymer Engineering - University of Miskolc • femgomze@uni-miskolc.hu

SERGEI N. KULKOV - Institute of Strength Physics and Materials Science of Siberian Branch of Russian Academy of Sciences - National Research Tomsk State University - kulkov@ms.tsc.ru

Érkezett: 2018. 01. 15. - Received: 15. 01. 2018. " https://doi.org/10.14382/epitoanyag-jsbcm.2018.6

\section{Abstract}

In this research work different pore forming methods and sintering temperatures were applied to create micropores in zirconia $\left(\mathrm{ZrO}_{2}\right)$, alumina $\left(\mathrm{Al}_{2} \mathrm{O}_{3}\right)$ and $\mathrm{ZrO}_{2}-\mathrm{MgO}$ composite ceramics in range from $4 \%$ up to $68 \%$. The authors have found that the used different pore forming additives and sintering temperatures are influenced very strong not only the pore sizes and their distributions but on final compression strengths also. Using aluminum hydroxide for pore forming at sintering temperature of $1450-1650{ }^{\circ} \mathrm{C} 62 \%$ porosity can be obtained at more than $200 \mathrm{MPa}$ compressive strength.

Keywords: alumina, aluminum hydroxide, ceramics, composites, microstructure, pore forming, porosity, sintering, zirconia

\section{Introduction}

Porous ceramic materials have found wide application in various fields and it is can be used as filter elements, catalyst carriers and heat-shielding elements. As compare to metals and polymers, ceramics have some advantages: high hardness, chemical inertness, wear resistance and thermal shock resistance, etc.

Operational properties of porous ceramic materials are largely determined by the parameters of the internal structure, such as pore volume, average pore size, shape and their contiguity. For example, a material with closed porosity and low thermal conductivity can be used as a thermal barrier, while open and connected polymodal porosity, combined with chemical inertness, is applicable to the filtration of liquids and gases.

Modern methods of pore structure formation make it possible to obtain porous ceramics with the necessary properties and characteristics by introducing various pore-forming additives into the initial powder compositions and sintering parameters changing. At present time there are several technologies for the production of porous ceramic materials: sintering of disperse systems at low temperatures, introduction of a pore-former or gas bubbles into a curable ceramic slurry. In [1] is described a method for obtaining a highly porous, up to 95\%, ceramic, based on the rapid freezing and freeze-drying of a ceramic suspension. This makes it possible to obtain dendritic pore structures that can be good gas-filtering elements. The creation of macroporous structure described in [2] allows obtaining pores morphology similar to inorganic bone matrix. The choice of the method for creating the material pore structure
Ales S. BUYAKOV

is graduated in the National Research Tomsk Polytechnic University, as an engineer and he actually continues his study as $\mathrm{PhD}$ student under supervision of Prof. S. N. Kulkov in the Institute of Strength Physics and Materials Science SB RAS.

Ruslan V. LEVKOV is graduated in the National Research Tomsk State University. At present he is working in the Institute of Strength Physics and Materials Science SB RAS.

Svetlana P. BUYAKOVA is Doctor of Sciences since 2008, full Professor since 2013. She is specialist in material sciences of ceramic and ceramic matrix composites based on oxides and carbides. She is author and co-author of more than 100 papers. Now, she is chief scientist in IS PMS RAS and professor in Tomsk State University and Tomsk Polytechnic University. Her teaching experience: Introduction to materials science, Fundamentals of materials engineering, Materials and their applications.

Emese KUROVICS is graduated in the University of Miskolc, Department of Ceramics and Silicate Engineering as a material engineer, where she actually continues her study as PhD student under supervision of Prof. L. A. Gömze.

László A. GÖMZE is establisher and professor of the Department of Ceramics and Silicate Engineering in the University of Miskolc, Hungary. He is author or coauthor of 2 patents, 6 books and more than 300 scientific papers. Recently, he is the chair of the International Organization Board of ic-cmtp5 the 5th International Conference on Competitive Materials and Technological Processes (2018).

Sergei N. KULKOV is professor of the Tomsk State University and head of Department of Ceramics in the Institute of Strength Physics and Materials Science of the Russian Academy of Science since 1989. His research works are represented in 5 books, more than 150 articles, 18 patents and many International Symposiums and Conferences. At present he is head of department „Theory of Strength and Mechanic of Solids", member of "The American Ceramic Society” of "The APMI International" and the DYM AT Society (France).

is determined by the necessary morphology, functional properties and the corresponding application of the future product. Nevertheless, many of the technologies like additive technologies [3-5] for obtaining the necessary pore structure can be difficult or expensive, that prevents their wide use $[6,7]$.

One of the most common technologies for creating pore structure in ceramic materials is introduction of pore-forming particles into the initial powder composition followed by pressing and sintering. The selection of pore-former depends on the pores required average size and shape. The poreforming material should be thermally removed particles, for example paraffin, rosin, ammonium carbonate and some types of polymers.

Another common method of porosity formation is the decomposition of hydroxides, for example, aluminum, zirconium, magnesium, etc. to their oxides with $\mathrm{H}_{2} \mathrm{O}$ evaporation. This method of pore formation avoids the presence of impurities on the internal surfaces of the porous ceramic matrix [8]. 
Despite the fact that such studies devoted a considerable amount of work, comprehensive studies on the porosity formation laws in ceramics based on oxides using various methods of pore formation is not enough.

The purpose of this work is to study a pore structures formation in ceramics based on alumina and zirconia using organic pore-forming particles, hydroxides and variation in the sintering parameters.

\section{Materials and methods}

It have been studied ceramic composites $\mathrm{ZrO}_{2}-\mathrm{MgO}$ with 0-100 wt. \% $\mathrm{MgO}, \mathrm{ZrO}_{2}-\mathrm{Al}_{2} \mathrm{O}_{3}$ with $0-75$ wt.\% of $\mathrm{Al}(\mathrm{OH})_{3}$ and $\mathrm{Al}_{2} \mathrm{O}_{3}$ with $0-100$ wt. $\%$ of $\mathrm{Al}(\mathrm{OH})_{3}$ in the initial powder compositions.

The mean size of particles of $\mathrm{ZrO}_{2}$ powder stabilized with $3 \mathrm{~mol} . \% \mathrm{MgO}$ were $0.5-6 \mu \mathrm{m}$, magnesia were $7 \mu \mathrm{m}$. Alumina powder was obtained by annealing $\mathrm{Al}(\mathrm{OH})_{3}$ at $1100{ }^{\circ} \mathrm{C}$, the particle size was $50-100 \mu \mathrm{m}$. The particle size of the alumina powder was $50-100 \mu \mathrm{m}$.

Powder mixtures were obtained by mechanical mixing of powder components and cold uniaxial pressing at $190 \mathrm{MPa}$ using steel mould, followed by sintering in an air atmosphere with holding time one hour.

Materials with bimodal porosity were obtained by adding and burning out ultra-high molecular weight polyethylene (UHMWPE) particles with an average size of $50 \mu \mathrm{m}$, adding to the initial powder mixtures, followed by annealing at $300^{\circ} \mathrm{C}$ for removing polyethylene particles and sintering at $1600{ }^{\circ} \mathrm{C}$ similar [9]. Two other methods of pore formation were used in $\mathrm{ZrO}_{2}-\mathrm{MgO}$ composite as changing of sintering temperature from $1200^{\circ} \mathrm{C}$ to $1600{ }^{\circ} \mathrm{C}$ and decomposition of $\mathrm{Al}(\mathrm{OH})_{3}$ with evaporation of $\mathrm{H}_{2} \mathrm{O}$ sintering at temperatures $1450-1650{ }^{\circ} \mathrm{C}$ $[10,11]$.

The microstructure was studied by scanning electron microscope; pore volume was measured by the Archimedes method. The compressive strength was determined by using a universal testing machine with a constant strain rate $7^{\star} 10^{-4} \mathrm{~s}^{-1}$.

\section{Results and discussion}

On figure 1 are shown that $\mathrm{ZrO}_{2}-\mathrm{MgO}$ compacts with highest sintering temperature had a minimum porosity $-4 \%$. Decreasing of sintering temperature was accompanied by a nonlinear increasing of pore volume up to $60 \%$. The average pore size of ceramics sintered at $1600^{\circ} \mathrm{C}$ were $8 \mu \mathrm{m}$, with standard deviation, $\sigma$, is $6 \mu \mathrm{m}$, these data are illustrated by microphotography on figure 2. Decreasing of sintering temperature leads to increasing of the pore sizes from $14 \mu \mathrm{m}$ and $\sigma=11 \mu \mathrm{m}$ for $1500{ }^{\circ} \mathrm{C}$ and 17 $\mu \mathrm{m}$ and $\sigma=10 \mu \mathrm{m}$ for $1400^{\circ} \mathrm{C}$.

Figures 3 shows a scanning electron microscopy image of the $\mathrm{ZrO}_{2}-\mathrm{Al}_{2} \mathrm{O}_{3}-\mathrm{Al}(\mathrm{OH})_{3}$ fracture surface, and figure 4 shows a polished surface of $\mathrm{Al}_{2} \mathrm{O}_{3}-\mathrm{Al}(\mathrm{OH})_{3}$ ceramic material after sintering at $1600{ }^{\circ} \mathrm{C}$. During the sintering alumina one can observed a decomposition of hydroxide and formation of irregular shape pores. Estimation of pore size distribution are shown that the average pore size is $2.1 \mu \mathrm{m}$ in $\mathrm{ZrO}_{2}-\mathrm{Al}_{2} \mathrm{O}_{3}$ ceramic and $4 \mu \mathrm{m}$ in $\mathrm{Al}_{2} \mathrm{O}_{3}$.

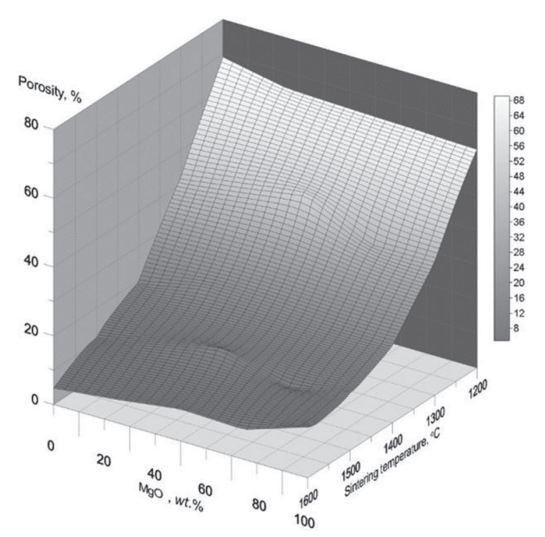

Fig. 1. Porosity of $\mathrm{ZrO}-\mathrm{MgO}$ vs. composition and sintering temperature 1. ábra A porózus $\mathrm{ZrO}_{2}-\mathrm{MgO}$ összetétele és szinterelési hömérséklete

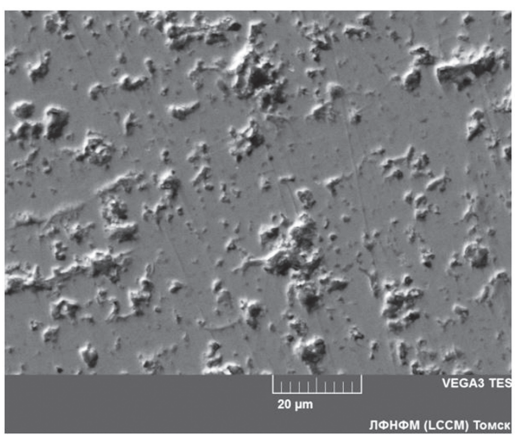

a)

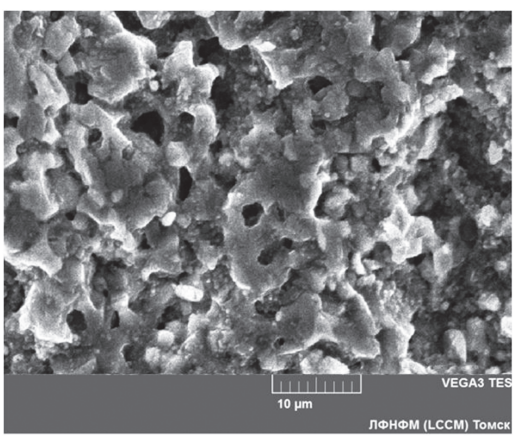

b)

Fig. 2. The microstructure of the polished surface (a) and the fracture surface (b) of the $\mathrm{ZrO}_{2}-50 w t$. $\% \mathrm{MgO}$ ceramic sintered at $1400{ }^{\circ} \mathrm{C}$.

2. ábra $\mathrm{Az} 1400^{\circ} \mathrm{C}$-on szinterelt $\mathrm{ZrO}_{2}-50 \mathrm{~m} \% \mathrm{MgO}$ kerámia csiszolat (a) és töretfelületének (b) mikrostruktúrája

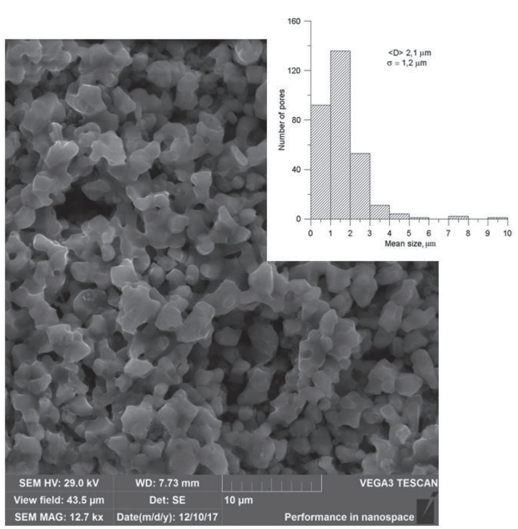

Fig. 3. a) Microstructure of the ceramic fracture surface, based on $\mathrm{ZrO}_{2}$ with the $75 \%$ addition of aluminum hydroxide. Sintering temperature $1600{ }^{\circ} \mathrm{C}$ and pore size distribution

3. ábra $\mathrm{Az} 1600^{\circ} \mathrm{C}$-on szinterelt $75 \%$ alumínium-hidroxid adalékkal készült $\mathrm{ZrO}_{2}$ kerámia töretfelületének a szerkezete és a pórusméret eloszlása 


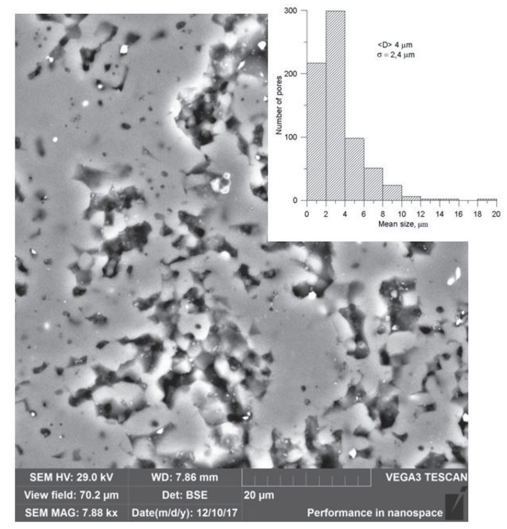

Fig. 4. a) Microstructure of the polished surface of ceramics alumina-75\% aluminum hydroxide; Sintering temperature $1600{ }^{\circ} \mathrm{C}$ and pore size distribution

4. ábra $\mathrm{Az} 1600^{\circ} \mathrm{C}$-on szinterelt $75 \%$ alumínium-hidroxid adalékkal készült $\mathrm{Al}_{2} \mathrm{O}_{3}$ kerámia csiszolat felületének szerkezete és a pórusméret eloszlása

On figures 5 are shown the dependences of pore volume in $\mathrm{ZrO}_{2}-\mathrm{Al}_{2} \mathrm{O}_{3}$ and $\mathrm{Al}_{2} \mathrm{O}_{3}$ ceramics after sintering vs. aluminum hydroxide content and sintering temperature. It can be seen that in $\mathrm{ZrO}_{2}-\mathrm{Al}_{2} \mathrm{O}_{3}$ ceramics the pore volume increases with increasing of hydroxide concentration and almost does not changes with sintering temperature. Alumina ceramic, obtained with an aluminum hydroxide addition showed an increasing of porosity with increasing of $\mathrm{Al}(\mathrm{OH})_{3}$ concentration, but decreasing with increasing of sintering temperature, figure 6 .

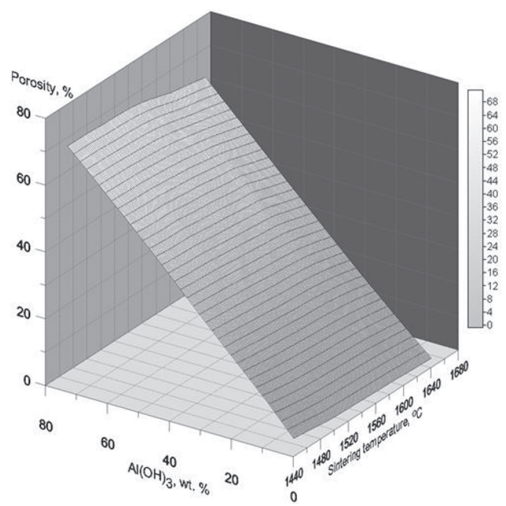

Fig. 5. Dependence of pore volume in ceramics based on $\mathrm{ZrO}_{2}$ vs. aluminum hydroxide content and sintering temperature

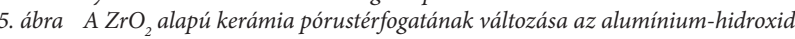
tartalom és a szinterelési hömérséklet szerint

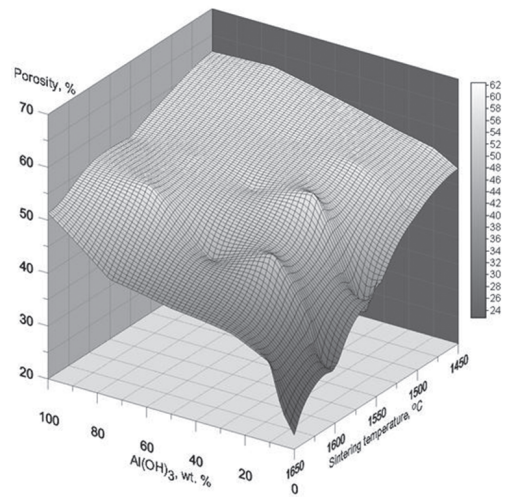

Fig. 6. Dependence of pore volume in ceramics based on $\mathrm{Al}_{2} \mathrm{O}_{3}$ from the concentration of aluminum hydroxide and the sintering temperature

6. ábra $\mathrm{Az} A \mathrm{Al}_{2} \mathrm{O}$ alapú kerámia pórustérfogatának változása az alumínium-hidroxid tartalom és a szinterelési hömérséklet szerint
Addition of UHMWPE to the $\mathrm{ZrO}_{2}-\mathrm{MgO}$ composite leads to creation a bimodal pore structure and increases the average micropores size up to $30 \mu \mathrm{m}$ without a dependence on the $\mathrm{MgO}$ concentration. As one can see from figure 7 that in sintered $\mathrm{ZrO}_{2}-\mathrm{MgO}$ ceramic there are two pore types - with average size about 100 and $10 \mu \mathrm{m}$. The large pores have the morphology of the pore-forming particles - spherical-shape which can be both isolated and connected. Pores of smaller sizes are formed by the compacting of powder particles parameters and its mean size is $29 \mu \mathrm{m}$. The pore size distributions are shown on Figure 8 and as one can conclude from Table 1 its does not depends on $\mathrm{MgO}$ content.
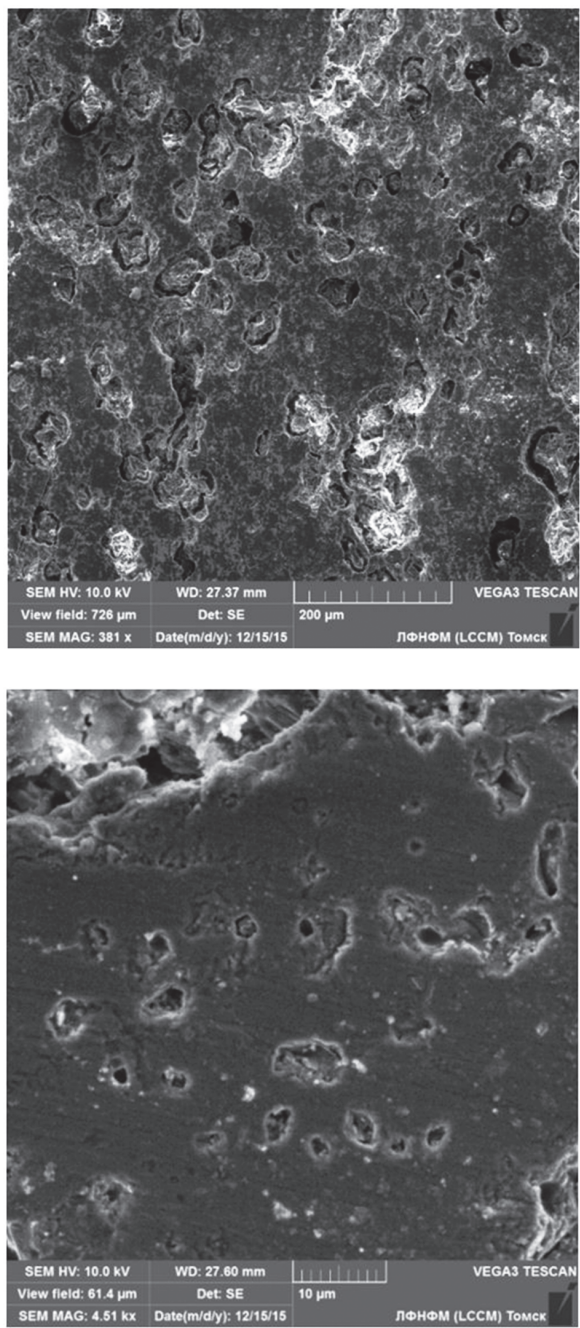

Fig. 7. Microstructure of $\mathrm{ZrO}_{2}-\mathrm{MgO}$ porous ceramics

7. ábra A porózus $\mathrm{ZrO} 2-\mathrm{MgO}$ kerámia mirkoszerkezete

\begin{tabular}{cccc}
$\begin{array}{c}\text { Mg0, } \\
\text { mass } \\
\%\end{array}$ & $\begin{array}{c}\text { The average size of } \\
\text { micropores, } \boldsymbol{\mu m} ; \\
\text { Standard deviation, } \\
\boldsymbol{\mu m}\end{array}$ & $\begin{array}{c}\text { The average size of } \\
\text { macropores, } \boldsymbol{\mu m} ; \\
\text { Standard deviation, } \\
\boldsymbol{\mu m}\end{array}$ & $\begin{array}{c}\text { Porosity, } \\
\text { vol. \% }\end{array}$ \\
\hline 0 & $29 ; \sigma=19$ & $98 ; \sigma=31$ & 45 \\
25 & $30 ; \sigma=23$ & $104 ; \sigma=21$ & 43 \\
50 & $27 ; \sigma=17$ & $94 ; \sigma=27$ & 45 \\
75 & $26 ; \sigma=17$ & $101 ; \sigma=30$ & 49 \\
100 & $28 ; \sigma=20$ & $105 ; \sigma=27$ & 47
\end{tabular}

Table 1. The average pore size of $\mathrm{ZrO}_{2}-\mathrm{MgO}$ ceramics

1. táblázat A ZrO2-MgO kerámiák átlagos pórusmérete 

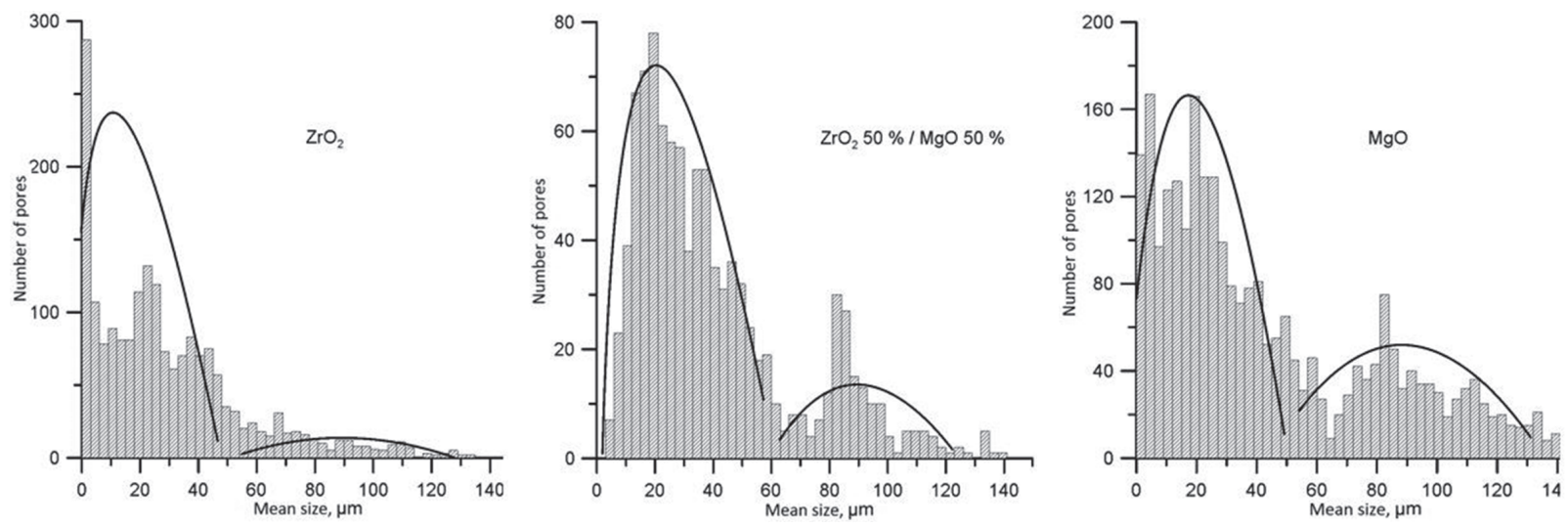

Fig. 8. Pore size distribution according to composition

8. ábra A pórusméret-eloszlás az összetétel szerint

Pore-forming technologies, based on the changes of sintering temperature and $\mathrm{Al}(\mathrm{OH})_{3}$ and UHMWPE addition, makes it possible to obtain micropores with an average size up to $17 \mu \mathrm{m}$. Average pore size of ceramic obtained with $\mathrm{Al}(\mathrm{OH})_{3}$ addition in initial powders were $2.1 \mu \mathrm{m}$ in $\mathrm{ZrO}_{2}-\mathrm{Al}_{2} \mathrm{O}_{3}$ ceramic and 4 $\mu \mathrm{m}$ for $\mathrm{Al}_{2} \mathrm{O}_{3}$ ceramic.

Increasing of $\mathrm{ZrO}_{2}-\mathrm{MgO}$ composite sintering temperature from 1200 to $1600{ }^{\circ} \mathrm{C}$ leads to a decrease in porosity from 68 to $4 \%$. The average size of micropores decreases from 17 to $8 \mu \mathrm{m}$ without significant dependence of components in the initial powder composition.

Determination of compression strength of a $\mathrm{ZrO}_{2}-\mathrm{MgO}$ composite, sintered without adding pore-forming particles are shown, that strength increases with sintering temperature increasing, the maximum strength is $230 \mathrm{MPa}$ can be achieved after sintering at highest temperature $1600{ }^{\circ} \mathrm{C}$, figure 9 .

Figures 10 and 11 are shown the compression strength of $\mathrm{ZrO}_{2}-\mathrm{Al}_{2} \mathrm{O}_{3}$ and $\mathrm{Al}_{2} \mathrm{O}_{3}$ ceramics. Both ceramics showed the increasing of strength with increasing of sintering temperature and decreasing of aluminum hydroxide concentration in initial powder composition. Ceramics based on $\mathrm{ZrO}_{2}$ has maximum compressive strength $64 \mathrm{MPa}$ after sintering at $1650{ }^{\circ} \mathrm{C}$ without the aluminum hydroxide addition. The minimum compressive strength was $8 \mathrm{MPa}$ after sintering at $1450{ }^{\circ} \mathrm{C}$ and with aluminum hydroxide addition $75 \%$. At the maximum sintering temperature and the minimum content of aluminum hydroxide the $\mathrm{Al}_{2} \mathrm{O}_{3}$-based ceramic had compressive strength $165 \mathrm{MPa}$. The minimum compressive strength was $10 \mathrm{MPa}$ for ceramic sintered as aluminum hydroxide content with a sintering temperature $1450{ }^{\circ} \mathrm{C}$. The compression strength of the $\mathrm{ZrO}_{2}-\mathrm{MgO}$ composite with bimodal porosity increases with an increasing of $\mathrm{MgO}$ content in the composition from 18 to $33 \mathrm{MPa}$.

\section{Conclusion}

Thus, the methods of pore volume formation in ceramics allow to obtain the pore volume in $\mathrm{ZrO}_{2}$ and $\mathrm{Al}_{2} \mathrm{O}_{3}$ ceramics in the range from $4 \%$ to $68 \%$ and sintering temperature increasing leads to decreasing of the average pore size and pore volume.

It have been found that the introduction of pore-forming

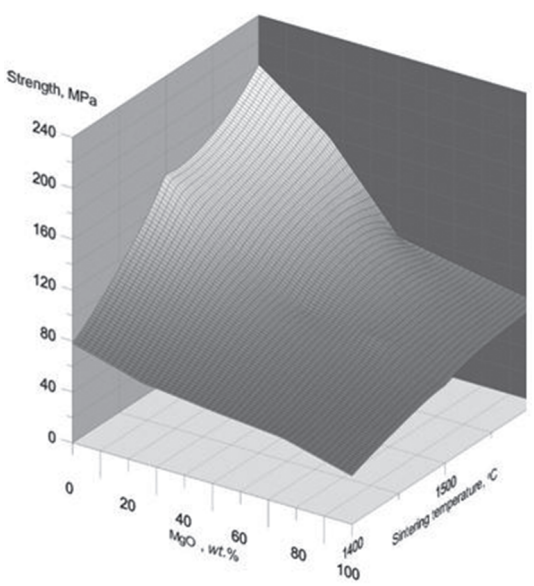

Fig. 9. Dependence of compressive strength of $\mathrm{ZrO}_{2}-\mathrm{MgO}$ vs. composition and sintering temperature

9. ábra $\mathrm{A} \mathrm{ZrO}_{2}-\mathrm{MgO}$ kerámia nyomószilárdságának változása az összetétel és a szinterelési hömérséklet függvényében

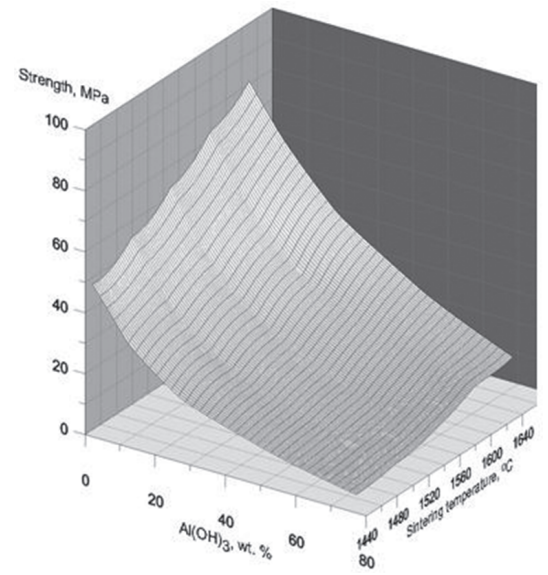

Fig. 10. Dependence of the compressive strength of $\mathrm{ZrO}_{2}$-based ceramics vs. the sintering temperature and aluminum hydroxide content

10. ábra $\mathrm{A} \mathrm{ZrO}$ alapú kerámia nyomószilárdságának változása az alumínium-hidroxid tartalom és a szinterelési hömérséklet szerint

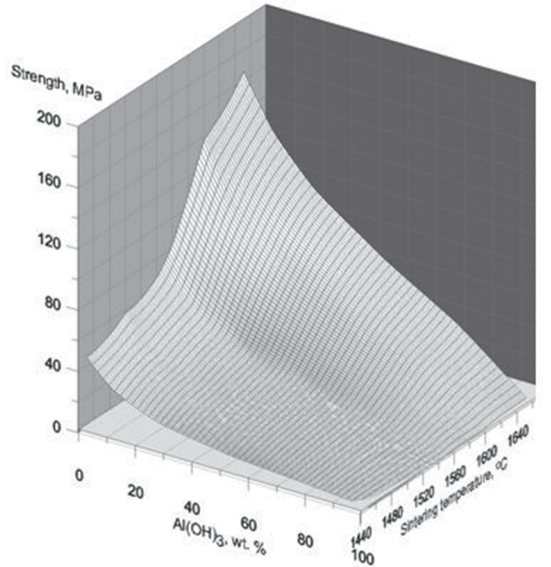

Fig. 11. Dependence of the compressive strength of $\mathrm{Al}_{2} \mathrm{O}_{3}$-based ceramics vs. the sintering temperature and aluminum hydroxide content

11. ábra $\mathrm{Az}_{\mathrm{Al}} \mathrm{O}_{3}$ alapú kerámia nyomószilárdságának változása az alumínium-hidroxid tartalom és a szinterelési hőmérséklet szerint 
particles into the $\mathrm{ZrO}_{2}-\mathrm{MgO}$ initial powder composition and sintering at $1600{ }^{\circ} \mathrm{C}$ makes it possible to obtain a pore structure inheriting the morphology of the pore-forming particles. The maximum compressive strength was $33 \mathrm{MPa}$. The compression strength of $\mathrm{ZrO}_{2}-\mathrm{MgO}$ ceramic obtained without the introduction of pore-forming particles reaches up to $200 \mathrm{MPa}$.

Addition of aluminum hydroxide to $\mathrm{Al}_{2} \mathrm{O}_{3}$ with sintering at temperatures $1450-1650{ }^{\circ} \mathrm{C}$ allows to achieve a porosity of up to $62 \%$, while the compressive strength is $220 \mathrm{MPa}$.

\section{Acknowledgement}

This work was carried out with partial support of project \#14.584.21.0026 (RFMEFI58417X0026).

\section{References}

[1] Zhang, H. - Cooper, A. I.: Aligned porous structures by directional freezing, Adv. Mater. 19 (2007) 1529-1533;

[2] Cesarano, J. - Dellinger, J. G. - Saavedra, M. P. - Gill, D. D. - Jamison, R. D. - Grosser, B. A. - Sinn-Hanlon, J. M. - Goldwasser, M. S.: Customization of load bearing hydroxylapatite lattice scaffolds, Int. J. Appl. Ceram. Technol. 2 (2005) 212-220;

[3] Lisachuk, G. V. - Kryvobok, R. V. - Fedorenko, E. Y. - Zakharov, A. V.: Ceramic radiotransparent materials on the basis of $\mathrm{BaO}-\mathrm{AL}_{2} \mathrm{O}_{3}-\mathrm{SiO}_{2}$ and $\mathrm{SrO}-\mathrm{Al}_{2} \mathrm{O}_{3}-\mathrm{SiO}_{2}$ systems //Epitoanyag-Journal of Silicate Based \& Composite Materials. - 2015. - T. 67. - №. 1.

http://dx.doi.org/10.14382/epitoanyag-jsbcm.2015.4

[4] Živcová, Z. - Gregorová, E. - Pabst, W. - Smith, D. S. - Michot, A. Poulier, C. (2009): Thermal conductivity of porous alumina ceramics prepared using starch as a pore-forming agent. Journal of the European Ceramic Society, 29(3), 347-353;

[5] Werner, J. - Linner-Krčmar, B. - Friess, W. - Greil, P. (2002): Mechanical properties and in vitro cell compatibility of hydroxyapatite ceramics with graded pore structure. Biomaterials, 23(21), 4285-4294;

[6] El Mir, A. - Nehme, S. G. - Nehme, K.: In situ application of high and ultra high strength concrete //Építöanyag 2016. - №. 1. - p. 20. http://dx.doi.org/10.14382/epitoanyag-jsbcm.2016.4

[7] Torres, G. M. R. - Medina, J. Z. - García, M. E. C.: Synthesis and characterization of Zirconia-Yttria nanoparticles in t'phase by sol-gel and spray drying //Építöanyag - 2016. - №. 4. - p. 120. http://dx.doi. org/10.14382/epitoanyag-jsbcm.2016.21
[8] Buyakov, A. S. - Kulkov, S. N. (2017, September): Abnormal behavior of $\mathrm{ZrO}_{2}-\mathrm{MgO}$ porous ceramic composite under compression. In AIP Conference Proceedings (Vol. 1882, No. 1, p. 020010). AIP Publishing;

[9] Savchenko, N. L. - Sablina, T. Y. - Sevostyanova, I. N. - Buyakova, S. P. Kulkov, S. N. (2016): Deformation and Fracture of Porous Brittle Materials Under Different Loading Schemes. Russian Physics Journal, 58(11), 15441548 ;

[10] Ayininuola, G. M. - Adekitan, O. A.: Compaction characteristics of lateritic soils stabilised with cement-calcined clay blends //Épitöanyag 2017. - №. 2. - P. 34. https://dx.doi.org/10.14382/epitoanyag-jsbcm.2017.7

[11] Ayub, N. - Rafique, U.: Synthesis and characterization of aluminosilicates $\left[\mathrm{Zn}_{3}\right.$ (BTC)2] hybrid composite materials //Építöanyag - 2017. - №. 3. - P. 98. https://dx.doi.org/10.14382/epitoanyag-jsbcm.2017.17

Ref.:

Buyakov, Ales S. - Levkov, Ruslan V. - Buyakova, Svetlana P. Kurovics, Emese - Gömze, László A. - Kulkov, Sergei N. : Formation of Pore Structure in Zirconia-Alumina Ceramics Építőanyag - Journal of Silicate Based and Composite Materials, Vol. 70, No. 1 (2018), 27-31. p. https://doi.org/10.14382/epitoanyag-jsbcm.2018.6

Pórusszerkezetek létrehozása cirkónium-oxid alumínium-oxid kerámiákban

Jelen kutatómunkában különbözó pórusképzó módszerek és szinterelési hômérsékletek alkalmazásával cirkóniumoxid, alumínium-oxid és ZrO2-MgO kerámia kompozitokban 4-68\%-os mikropórus szerkezetet hoztak létre. A szerzők megállapították, hogyazalkalmazottkülönbözôpórusképzô adalékoknak és szinterelési hómérsékleteknek nem csak a pórusok méretére és elhelyezkedésére van jelentôs hatása, hanem a nyomószilárdságra is. Pórusképzô adalékként alumínium-hidroxidot és $1450-1650^{\circ} \mathrm{C}$-os szinterelési hômérsékletet alkalmazva 62\%-os porozitás érhetô el több mint 200MPa-os nyomószilárdsággal.

Kulcsszavak: alumínium-oxid, alumínium-hidroxid, kerámiák, kompozitok, mikroszerkezet, pórusképzés, porozitás, szinterelés, cirkón-dioxid

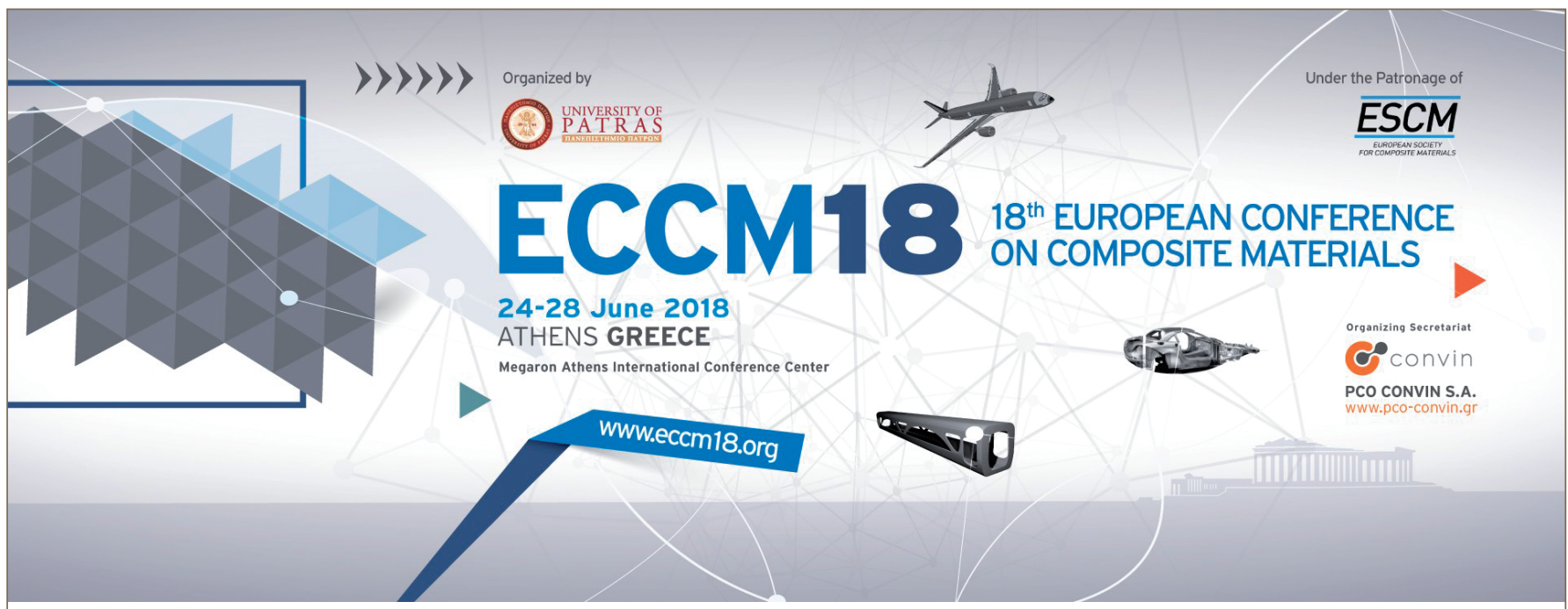

The 18th International Conference on Composite Materials is held biannually. Around 1,000 participants will take part in ICCM18, which has a multidisciplinary program for specialists in composite materials. ICCM18 is associated with other academic societies of related fields to build a more successful conference. 